\title{
Glossary to the judgment of the Court of Appeal in Katowice of 25 April 2018, file no. I ACA 1056/17
}

\section{Introduction}

In the thesis of the voted judgment, the Court of Appeal in Katowice stated:

Although Article 448 of the Civil Code also applies to the protection of personal goods of legal persons, in the case of legal persons, the criteria for the infringement of personal goods are somewhat different than in the case of natural persons. While in the case of natural persons, it is possible to analyse whether subjective or objective criteria for infringement of personal goods must be taken into account, in the case of legal persons, the objective criteria for infringement of personal goods are decisive but at the same time the only relevant. Legal persons cannot feel the harm done to them as people do, and it is impossible to take into account the negative feelings of the people who form the personal subsistence of the legal person in this respect. Self-esteem or self-respect requires the ability to perceive one's existence subjectively. Such perceptions cannot, in principle, be applied to a legal person. When deciding on a claim based on Article 448 of the Civil Code, the court should first decide whether there are grounds for refusing the claim. The circumstances justifying the dismissal of the claims in question include the degree of guilt of the perpetrator and the harm suffered, the type of personal goods violated (this is where the issue of violation of the goods of the legal person should be considered), the inappropriate conduct of the injured party himself.

* Dr., Univeristy of Bialystok; e-mail: p.konik@uwb.edu.pl, https://orcid.org/ 0000-0001-7766-2887. 
The position expressed in the above thesis concerns an important and complex issue relating to a claim for monetary compensation in case of infringement of the personal goods of a legal person. The main observation made by the Court of Appeal is actually in line with the explicit suggestion of the legislator contained in Article 43 of the Civil Code, ${ }^{1}$ which indicates that the provisions on the protection of personal goods of natural persons apply accordingly to legal persons. The reference to the application of some regulation to another issue "adequately" presupposes, on the one hand, a great similarity between the two issues, but at the same time serious differences between them. Consequently, some provisions relating to the personal goods of natural persons may not apply at all to the personal goods of legal persons, and some of them may need to be modified accordingly. Only some will be directly applicable. In our case, this means, first of all, that the personal goods of legal persons do not overlap with those of natural persons, which may subsequently also affect the question of the legal remedies available to legal persons and their scope.

\section{Personal rights of natural persons and personal rights of legal persons}

The difference in the construction of natural and legal persons translates primarily into a different catalogue of these goods in relation to both categories of persons. For example, legal persons, because they have no carnality (physicality), do not have a good in the form of health, a sense of belonging to a certain gender or image, and because they have no family life, there is no good in the form of worship after a deceased close person. As the Court of Appeal stated in the voted verdict, ${ }^{2}$ legal persons also do not have the possibility to feel, nor the ability to subjectively perceive their existence and, consequently, the awareness of their own value or respect

1 Act of 23 April 1964 Civil Code (consolidated text in Journal of Laws 2019, item 1145), hereinafter referred to as "Civil Code".

2 Referring to the judgment of the Supreme Court of September 24, 2008, ref. I CSK 126/08, OSNC-ZD 2009/2/58. This position was later accepted in the Court of Appeal in Warsaw of February 14, 2019, I ACa 1354/17, LEX no. 2637897. 
for themselves. So they don't have the personal good in the form of dignity. ${ }^{3}$ It is also difficult to talk about conscience in relation to them. As a result, Article 23 of the Civil Code cannot be directly related to legal persons. On the other hand, to this category of persons, the provisions concerning measures of non-financial (non-material) protection and their premises, provided for in Article $24 \S 1,1$ and 2 sentences, of the Civil Code, will apply directly, ${ }^{4}$ subject to the reservation indicated by the Court of Appeal of the application to legal persons of the criterion of objective impairment.

\section{Monetary compensation for the non-material harm caused by the infringement of the personal rights of the legal person}

Greater doubts accompany the question of monetary compensation for the non-material harm caused by the infringement of personal goods of a legal person. The very admissibility of such a claim is quite commonly accepted, ${ }^{5}$ but the opposite position was also represented. ${ }^{6}$ With regard to monetary compensation for non-material harm, although the Court of Appeal indicated very generally that a legal person cannot feel harm like a natural person, it referred in this respect to the decision of the Supreme Court of 24 September 2008, which explained that this means that it cannot be about harm in the form of negative feelings (an emotional injury) - pain and suffering (physical and mental). In the general legal consciousness, they are perceived as constituting the essence of the non-material injury of

3 See the judgment of the Supreme Court of 24 September 2008, Case No. I CSK 126/08, OSNC-ZD 2009/2/58. In the doctrine see J. Wierciński, Niemajatkowa ochrona czci, Warszawa 2002, p. 68; M. Pazdan, in: Prawo cywilne - część ogólna, ed. M. Safjan, Warszawa 2007, p. 1121.

4 Similarly, the Court of Appeal in Warsaw in the judgment of 11 April 2017, VI ACa 1906/15, LEX no. 2394849.

5 See judgment of the Supreme Court of 15 December 1975, I CR 887/75, not published; judgment of the Supreme Court of 24 September 2008, ref. I CSK 126/08, OSNC-ZD 2009/2/58; judgment of the Court of Appeal in Warsaw of 14 February 2019, I ACa 1354/17, LEX no. 2637897.

6 See the judgment of the Court of Appeal in Krakow of 28 September 1999, I ACa 464/99, Transformacje Prawa Prywatnego 2002, no. 3, p. 131; judgment of the Court of Appeal in Warsaw of 9 February 2007, VI ACa 960/06, Apelacja. Sąd Apelacyjny w Warszawie 2008, no. 1, item 103. 
natural persons. This is also visible in the perception of the monetary compensation itself, as a material measure of protection, but serving to compensate for the experienced sufferings (satisfaction with obtaining a financial benefit and the possibilities it gives is supposed to erase the negative previous experience). ${ }^{7}$ The perception that a legal person does not have the capacity to feel, and the assumption that this is not a case of feeling by persons who are the personal substrate of the person (including members of the authorities ${ }^{8}$ ), leads to the need to look more closely at the non-material harm to the legal person.

In the judgment of 24 September 2008, The Supreme Court stated that the non-material harm in personal goods of a legal person in such a case (without neglecting negative sensations) is non-material harm in a given personal good. Thus, it would be a matter of damage to the personal good itself, affected by the injurious event, i.e. the deterioration of that good. Such an objective approach can be considered as falling within the generally accepted definition of non-material harm, which is generally understood to mean as a type of harm of a non-material nature that reveals itself in a personal goods. ${ }^{9}$ However, it requires an in-depth analysis taking into account the nature of the specific good infringed. ${ }^{10}$ Taking into account the circumstances of the case in which the voted judgment was passed and the fact that the most frequently violated good of a legal person is probably its good name, this good may be taken into account in further considerations. The good name (reputation) of a legal person is related to its perception by others. In simple terms, it can be said that it is a positive opinion of other people about the entity, the respect that the person

7 See e.g. judgment of the Supreme Court of 11 January 2019, V CSK 558/17, LEX no. 2604670; judgment of the Supreme Court of 27 March 2019, V CSK 77/18, LEX no. 2652328; judgment of the Court of Appeal in Bialystok of 4 April 2019, I ACa 614/18, LEX no. 2669415.

8 This view is not without doubt, and the concept of bodies on which the functioning of legal persons is based seems flexible enough to take into account certain phenomena from the sphere of consciousness or feelings with an objective approach.

9 See e.g. M. Kaliński, in: Prawo zobowiązań - część ogólna, ed. A. Olejniczak, Warszawa 2009 , p. 91. It should be noted, however, that the importance of negative sensations is often pointed out anyway.

10 The nature of the infringed personal good as being of significant importance for determining the non-material harm and its extent is quite commonly indicated in jurisprudence. See e.g. judgment of the Court of Appeal in Warsaw of 15 May 2019, VI ACa 207/18, LEX no. 2847179. 
has for the environment. ${ }^{11}$ On the other hand, it is commonly accepted in the jurisprudence that statements which, objectively judged, attribute to a legal person inappropriate conduct which may result in the loss of trust necessary for its proper functioning in the scope of its tasks, are considered to violate the good name of a legal person. ${ }^{12}$

The objectification of the non-material harm to the personal goods of the legal persons can, above all, lead to its identification with the mere violation of a good name. It should be noted that the doctrine raises the question of whether the damage is a violation of a good or only the result of the violation. ${ }^{13}$ Even though the second position is more convincing, it is more important to recognise the need to distinguish between the infringement of a good itself due to an adverse event and the consequences of that infringement. Depending on the circumstances, both elements may occur simultaneously (which gives reason to identify them with each other) or at different times. In addition, other goods may also be affected.

Most importantly, however, the violation of a good does not necessarily lead to harm. ${ }^{14}$ In the case of a good name, as already indicated, the mere possibility for the legal person concerned to lose the trust of others is sufficient to accept a breach. On the other hand, for the purpose of a claim for monetary compensation, it is necessary that there be non-material harm, which should be distinguished from the harming event itself, consisting of personal good infringement. This results directly from Article 448 of the Civil Code, which clearly separates both premises. This does not, of course, rule out the possibility that the good affected by the harmful event will, at the same time, be the one in which the non-material harm is revealed, or even that it will be limited to that non-material harm alone. Given the objective nature of the non-material harm to the personal goods

11 See the judgment of the Court of Appeal in Poznan of 25 May 2006, I ACa 1331/05, LEX no. 278397; M. Pazdan, in: Prawo cywilne..., p. 1121.

12 Judgment of the Supreme Court of 14 November 1986, II CR 295/86, OSNC 1988, No. 2-3, item 40; judgment of the Supreme Court of 28 May 1999, I CKN 16/98, OSNC 2000, No. 2, item 25; judgment of the Supreme Court of 11 January 2007, II CSK 392/06, Civil Chamber 2008, no. 12, p. 40; judgment of Court of Appeal in Poznan of 25 May 2006, I ACa 1331/05, LEX no. 278397; judgment of Court of Appeal in Poznan of 10 July 2014, I ACa 444/14, LEX no. 1496033; judgment of the Supreme Court of 11 August 2016, I CSK 419/15, LEX no. 2087104.

13 See M. Kaliński, in: Prawo zobowiazań..., p. 95-96 and the literature given there.

14 M. Kaliński, in: Prawo zobowiąań..., p. 96. 
of legal persons, it can be concluded that such a situation will be typical. However, it cannot be assumed that the infringement itself is already a non-material harm in good name. Acceptance of such a proposal would lead to the need to accept the thesis that non-material harm would occur every time a good name is violated, which is too far-reaching. In order to establish that there has been non-material harm in the present case, it would be necessary to prove that the reputation, positive perception of the legal person concerned by other persons has indeed deteriorated and that the person is perceived less well than it was previously. Therefore, this would require taking into account the previous perception of the legal person by other persons and the identification of the entities to which certain reputational information has reached and that it has influenced the negative perception of the legal person. Thus, while the negative feelings of a natural person in relation to the fact that other people start to perceive him/ her worse or completely negatively could also be taken into account in the case of a violation of a natural person's good name, legal persons would in principle be left with only that objectively perceived, worsened state of good name, which before the violation was of a larger size, and after the violation is smaller or no longer exists at all.

With an objective approach to non-material harm to the personal goods of a legal person, the difficulty of converting non-material harm into cash benefits does not disappear. The fact that we do not estimate - as in the case of natural persons - negative feelings (pain, suffering) does not make things any easier. Even if we use an objective criterion, it is not at all easier to express in money the degree of change in the perception of a legal person by other people (the degree of deterioration in that person's reputation). As a result, the non-material harm, in this case, seems as difficult to grasp as when estimating these negative feelings in money.

Therefore, the difference in the construction of legal persons and, in particular, the inability to feel has a serious impact on their perception of non-material harm. This type of harm, detached from these negative feelings, has a slightly different form. At the same time, it should be emphasised, it appears narrower than the non-material harm to natural persons.

In the case of legal persons, especially those who have the status of an entrepreneur at the same time, the decisive importance of the material sphere can be seen (significant growth of this sphere of affairs, goods and interests, compared to the non-material sphere). It is difficult to assume that the non-material sphere does not exist at all for these persons. At 
the same time, however, it is difficult not to notice that the material purpose of the existence and operation of a legal person, especially one established to carry out business activity, is dominant and pushes any possible non-material interest into the background. It can also be said that personal goods are subject to it. This is particularly evident concerning the good name, since the importance of this personal good is seen precisely in the context of the trust needed to act in order to achieve a person's goal. It is, therefore, difficult to avoid qualifying the material sphere as dominant. Consequently, the violation of the good name may translate primarily into negative material consequences, i.e. material damage. It is this damage to property that will be of major importance. The non-material harm in the form of the reduction of the good name seems to be on the agenda. At the same time, it is not easy to separate the two spheres. However, it can be assumed that the material consequences would consist, in particular, of the fact that other entities negatively perceiving the legal person concerned do not establish business relations with it or, having previously established such relations, break them off. This lowers income, particularly in the form of lost profits, and appears on the part of the legal person concerned. Non-material harm would consist of a lower perception by others or a reduction in the degree of trust in the legal person. ${ }^{15}$

In both cases of harm, there is a noticeable difficulty in proving their origin and size. However, while it is required to determine the extent of the material harm precisely, there is, by its nature, a certain degree of discretion in the case of non-material harm. It appears that this difficulty of proof in relation to material harm often leads to monetary compensation for non-material harm which, like compensation for property, is of a monetary nature and is not accompanied by a similar rigour in demonstrating the extent of the damage. However, monetary compensation is, like damages, primarily compensatory in nature, and a possible repressive function is only ancillary. ${ }^{16}$ Monetary compensation should not, therefore, lead to the enrichment of the victim.

15 In the case of natural persons, into account would also have to be taken of the negative feelings of the person concerned that other parties judge him or her less well and perceive him or her as less trustworthy or untrustworthy.

16 Judgement of the Court of Appeal in Bialystok of 30 August 2017, I ACa 206/17, LEX no. 2390578; judgement of the Court of Appeal in Bialystok of 4 April 2019, I ACa 614/18, LEX no. 2669415; judgement of the Supreme Court of 30 April 2019, I CSK 181/18, 
Finally, it should be noted that the jurisprudence has already established a view on the optional ${ }^{17}$ and accessory (additional) nature of monetary compensation for non-material harm on personal goods. ${ }^{18}$ As a material measure to repair non-material harm, it is exceptional in nature. The basic and primary importance in this respect is attached to the non-material measures indicated in Article $24 \S 1$ of the Civil Code, such as making a statement of appropriate content and form. Monetary compensation should be awarded only if, after the application of non-material measures, some part of the non-material harm remains unremoved or cannot be removed by those measures. ${ }^{19}$ Even if the legal person's good name is infringed, the negative effects of such infringement should primarily be remedied by non-material measures. Only the finding that, despite such measures, the non-material harm would remain uncompensated would open the possibility of considering monetary compensation. The lack of prior application of these basic measures should be taken into account by the court deciding on monetary compensation. The absence of a prior declaration by the infringer of a good name should not lead to the automatic granting of pecuniary compensation if the non-material harm has not been remedied in any way.

\section{Conclusion}

The above considerations lead to the conclusion that the question of monetary compensation for the non-material harm to the personal goods of the legal persons is not presented in the same way as in the case of natural persons. The different nature and extent of the non-material harm to

LEX no. 2658504; judgement of the Court of Appeal in Warsaw of 4 July 2019, V ACa 459/18, LEX no. 2704208.

17 Judgment of the Supreme Court of 6 March 2019, I CSK 88/18, LEX no. 2630595.

18 See judgment of the Court of Appeal in Warsaw of 7 March 2019, I ACa 1819/17, LEX no. 2668868; judgment of the Supreme Court of 27 March 2019, V CSK 77/18, LEX no. 2652328; judgment of the Court of Appeal in Warsaw of 24 April 2019, I ACa 346/18, LEX no. 2750963; judgment of the Court of Appeal in Warsaw of 4 July 2019, V ACa 459/18, LEX no. 2704208.

19 Seejudgment of the Supreme Court of 27 March 2019, V CSK 77/18, LEX no. 2652328; judgment of the Court of Appeal in Warsaw of 4 July 2019, V ACa 459/18, LEX no. 2704208. 
the legal persons' personal goods justify the assumption that monetary compensation has a smaller scope here than for natural persons. The adequacy of the sums of money awarded should be considered accordingly. No less important than in the case of natural persons is the question of a total look at measures to protect the infringement of personal goods. Considering them in isolation and omitting an accessory character of monetary compensation for non-material harm may lead to an imbalance in the proportions between them and an excessive burden of the consequences of the infringement of personal goods.

\section{Bibliography}

Kaliński M., in: Prawo zobowiazań - część ogólna, ed. A. Olejniczak, Warszawa 2009. Pazdan M., in: Prawo cywilne - część ogólna, ed. M. Safjan, Warszawa 2007. Wierciński J., Niemajątkowa ochrona czci, Warszawa 2002.

\section{Sum mary}

The position expressed in the thesis of the judgment of the Court of Appeal in Katowice concerns an important and complex issue relating to a claim for monetary compensation in case of infringement of the personal goods of a legal person. The assumption that legal persons do not have the ability to feel like natural persons means that harm cannot be seen as these negative feelings - pain and suffering (physical and mental). The non-material harm to the personal goods of a legal person is, therefore, in a different form than that of a natural person. The considerations contained in the glossary are intended to determine what it is. They lead to the conclusion that the amount of non-material harm to the personal goods of a legal person is smaller than that of a natural person. This results in a smaller scope of monetary compensation applications for non-material harm to the personal goods of a legal person.

Key words: monetary compensation, non-material harm on the personal goods of a legal person, personal goods, non-material harm 


\section{GLOSA DO WYROKU SĄDU APELACYJNEGO W KATOWICACH Z 25 KWIETNIA 2018 R., I ACA 1056/17}

\section{Streszczenie}

Stanowisko przedstawione w tezie wyroku Sądu Apelacyjnego w Katowicach dotyczy ważnego i złożonego zagadnienia dotyczącego roszczenia o zadośćuczynienie pieniężne za naruszenia dobra osobistego osoby prawnej. Przyjęcie, że osoby prawne nie mają zdolności do odczuwania jak osoby fizyczne powoduje, że krzywda nie może być postrzegana jako owe negatywne doznania. Szkoda niemajątkowa na dobrach osobistych osoby prawnej ma więc inną postać niż przy osobach fizycznych. Rozważania zawarte w glosie zmierzają do ustalenia, na czym ona polega. Prowadzą one do wniosku, że rozmiar szkody niemajątkowej na dobrach osobistych osoby prawnej jest mniejszy niż w odniesieniu do osoby fizycznej. Wpływa to na mniejszy zakres stosowania zadośćuczynienia pieniężnego za szkodę niemajątkową na dobrach osobistych osoby prawnej.

Słowa kluczowe: zadośćuczynienie pieniężne, szkoda niemajątkowa na dobrach osobistych osoby prawnej, dobra osobiste, szkoda niemajątkowa

\section{КОММЕНТАРИЙ К РЕШЕНИЮ АПЕЛЛЯЦИОННОГО СУДА В ГОРОДЕ КАТОВИЦЕ ОТ 25 АПРЕЛЯ 2018 Г., І АСА 1056/17}

\section{Резюме}

Позиция, изложенная в тезисе решения Апелляционного суда в Катовице, касается важного и сложного вопроса, касающегося иска о возмещении денежной компенсации за нарушение личного неимущественного права юридического лица. Предположение о том, что юридические лица не способны чувствовать, как физические лица, означает, что нанесенный вред нельзя рассматривать как такие негативные ощущения. Таким образом, моральный неимущественный вред нанесенный юридическому лицу имеет иную форму, чем тот нанесенный физическим лицам. Соображения, содержащиеся в настоящем комментарии, направлены на то, чтобы определить ее сущность. Они приводят к выводу, что размер морального неимущественного вреда юридического лица меньше, чем по отношению к физическому лицу. Это приводит к уменьшению сферы применения возмещения морального вреда юридического лица в виде денежной компенсации.

Ключевые слова: денежная компенсация, моральный неимущественный вред юридического лица, личные права, неимущественный вред 